\title{
A rare case of Hodgkin's lymphoma presenting with papulonecrotic tuberculid
}

\author{
Kundan Mishra, ${ }^{1}$ Aditya Jandial, ${ }^{1}$ Kaniyappan Nambiyar, ${ }^{2}$ Pankaj Malhotra ${ }^{1}$
}

'Department of Internal Medicine, Post Graduate Institute of Medical Education and Research, Chandigarh, India ${ }^{2}$ Department of Pathology, Post Graduate Institute of Medical Education and Research, Chandigarh, India

Correspondence to Dr Kundan Mishra, mishrak20@ rediffmail.com

Accepted 15 June 2017

\section{DESCRIPTION}

A 78-year-old man complained of pruritic skin lesions over the trunk and all limbs and occasional fever for 3 months. He had papulonodular skin lesions with erythematous base involving anterior as well as posterior aspects of the trunk and all limbs with predilection for extensor surface (figure 1). Mantoux test was negative. Skin biopsy showed features of papulonecrotic tuberculid (figure 2) with a negative Mycobacterium tuberculosis PCR and acid-fast bacilli stain. CT scan of the chest and abdomen showed multiple, enlarged mediastinal and retroperitoneal lymph nodes (largest $2.4 \mathrm{~cm}$ ). Trucut biopsy and immunohistochemistry from retroperitoneal node revealed features of classical Hodgkin's lymphoma, nodular sclerosis

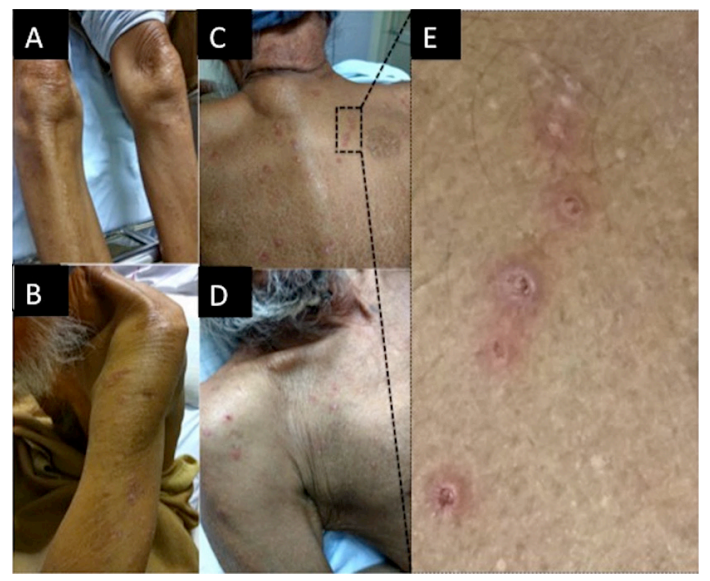

Figure 1 Papulonodular skin lesions with erythematous base involving lower limbs (A), upper $\operatorname{limb}(B)$, anterior as well as posterior aspect of trunk $(C, D)$ with predilection for extensor surface. Inset (E) showing distinct papulonodular lesions.

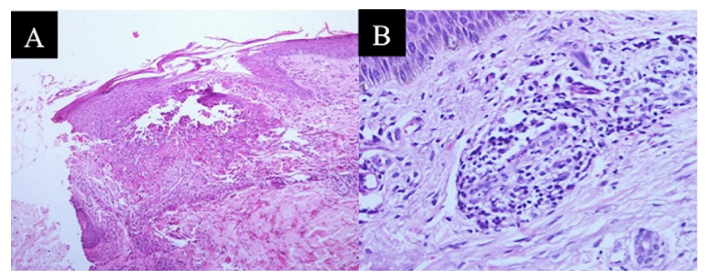

To cite: Mishra $K$, Jandial $A$, Nambiyar K, et al. BMJ Case Rep Published Online First: [please include Day Month Year]. doi:10.1136/bcr-2017 220484
CrossMark

Figure 2 (A) Skin biopsy showing wedge-shaped dermal necrosis with its broad base toward the epidermis and vasculitis, H\&E $\times 40$. (B) Skin biopsy showing vasculitis and interstitial granuloma with histiocytes, lymphocytes and few epithelioid cells, H\&E $\times 400$. variety with CD 15 and CD 30 positivity. In the absence of conclusive evidence of tuberculosis, he was treated with chemotherapy alone (oral prednisolone, etoposide, procarbazine and cyclophosphamide). Two months later, he is asymptomatic with partial resolution of skin lesions.

Papulonecrotic tuberculid possibly results from hypersensitivity to M. tuberculosis. Isolation of Mycobacterium from cultures as well as by PCR has been described in the previously reported cases. ${ }^{1}$ There has been evidence that antitubercular therapy is the treatment of this condition. $^{2}$

Paraneoplastic skin lesions have been associated with Hodgkin's lymphoma like icthyosis, acrokeratosis, urticaria, erythema multiforme and hyperpigmentation. ${ }^{3}$ However, there has not been any case report of Hodgkin's lymphoma presenting with papulonecrotic tuberculid when searched on PubMed. In our case, there was clinical and histopathological evidence of both the diseases in the same individual.

\section{Learning points}

- Papulonecrotic tuberculid is a rare manifestation of hypersensitivity to Mycobacterium tuberculosis.

- In immunocompromised patient, the purified protein derivative test, acid-fast bacilli stain and culture all might be negative; however, typical histopathological features can clinch the diagnosis of papulonecrotic tuberculid.

Contributors $\mathrm{KM}, \mathrm{AJ}, \mathrm{KN}$ and PM were involved in patient care at various stages. KN prepared the histopathology slides. KM and AJ prepared the manuscript, while all authors read it and agreed to it.

Competing interests None declared.

Patient consent Obtained.

Provenance and peer review Not commissioned; externally peer reviewed.

(C) BMJ Publishing Group Ltd (unless otherwise stated in the text of the article) 2017. All rights reserved. No commercial use is permitted unless otherwise expressly granted.

\section{REFERENCES}

1 Tirumalae R, Yeliur IK, Antony M, et al. Papulonecrotic tuberculidclinicopathologic and molecular features of 12 Indian patients. Dermatol Pract Concept 2014;4:17-22.

2 Sinha P, Sinha A, Baveja S, et al. A common but underreported entity of papulonecrotic tuberculid. Med I Armed Forces India 2015;71(Suppl 1):S237-9. 


\section{Images in...}

3 Lucker GP, Steijlen PM. Acrokeratosis paraneoplastica (Bazex syndrome) occurring with

Copyright 2017 BMJ Publishing Group. All rights reserved. For permission to reuse any of this content visit http://group.bmj.com/group/rights-licensing/permissions.

BMJ Case Report Fellows may re-use this article for personal use and teaching without any further permission.

Become a Fellow of BMJ Case Reports today and you can:

- Submit as many cases as you like

- Enjoy fast sympathetic peer review and rapid publication of accepted articles

- Access all the published articles

- Re-use any of the published material for personal use and teaching without further permission

For information on Institutional Fellowships contact consortiasales@bmjgroup.com

Visit casereports.bmj.com for more articles like this and to become a Fellow 